\title{
122. Cytogenetical Studies on the Japanese Raccoon Dog. XI \\ Specimens collected in Kanagawa-ken having a Single \\ Robertsonian Fission of the Pair No. 5 and having an Equal Number of Cells with \\ 2 and 3 B.Chromosomes*)
}

\author{
By Tosihide H. YosIDA**) and Masayasu Y. WADA***) \\ (Communicated by Sajiro Makino, M. J. A., Nov. 12, 1985)
}

Because of the wide spread of the B-chromosomes and the Robertsonian fission, the Japanese raccoon dogs (Nyctereutes procyonoides viverrinus) are very interesting species as the present authors described previously (Yosida et al. 1983, 1984, 1985; Yosida and Wada 1984a-d, 1985a-c). All 37 specimens examined so far by the present authors had 2, 3 and 4 B-chromosomes in their somatic and germ cells. The numerical variation of the B-chromosomes by nondisjunction, however, was observed in all of the specimens examined. Among 37 specimens the Robertsonian fission of the metacentric chromosomes has been observed in 8 specimens. In these specimens the chromosomes occurring the fission have been identified in 5 specimens by the G-banding analysis. Three specimens had the Robertsonian fission in the no. 8 chromosome, one specimen had in the no. 6 and the remaining one showed the fission in 3 chromosome pairs, nos. 5, 8 and 11 (Yosida and Wada 1984a). Although a single Robertsonian fission of the no. 5 chromosome has not yet been observed, it was found in one specimen collected in Kanagawa-ken. The present paper deals with the specimen with the Robertsonian fission of the no. 5 chromosome and also the other one specimen characterized by having an equal number of cells with 2 and 3 Bchromosomes.

Material and methods. Two female Japanese raccoon dogs (Nyctereutes procyonides viverrinus) (specimen nos. RD-8501 and RD-8503) were collected in the suburbs of Kawasaki-city and Yokohama-city, Kanagawa-ken, Japan. They were protected and maintained in the Yokohama Municipal Nogeyama Zoo for about 6 months, respectively. The chromosome observations were taken in the cultured cells from the skin biopsy by our routine procedure. The serial conventional Giemsa, G- and C-banding stainings were applied for the chromosome observations (Wada and Yosida 1984).

Results and discussion. 1) Specimen RD-8501 with an equal number of 2 and 3 B-chromosomes. This specimen was characterized by the somatic mosaic having the equal number of cells with 40 and 41 chromosomes. The former cells included the 2 B-chromosomes and the latter cells involved 3 B-chromosomes. Among 110 cells analysed 55 cells $(50.0 \%)$ had 2 B's and the remaining 55 cells $(50.0 \%)$ had 3 B's (Table I). Any Robertsonian fission of the autosomes was not observed in this specimen.

*) Contribution no. 1657 from the National Institute of Genetics, Japan.

**) National Institute of Genetics, Misima, Shizuoka-ken 411, Japan.

***) Amagi Wild Boar Park, Amagiyugashima, Shizuoka-ken 410-32, Japan. 
Table I. B-chromosomes and the Robertsonian fission in the Japanese raccoon dogs (RD-8501 and RD-8503) collected in Kanagawa-ken, Japan

\begin{tabular}{|c|c|c|c|c|c|}
\hline \multicolumn{6}{|c|}{ Specimen RD-8501 } \\
\hline Chrom. nos. & 40 & 41 & & \multirow{2}{*}{$\begin{array}{l}\text { Robert. } \\
\text { fission }\end{array}$} & \multirow{2}{*}{$\begin{array}{l}\text { Total no. of cells } \\
\text { observed }(\%)\end{array}$} \\
\hline No. of B's & 2 & 3 & & & \\
\hline $\begin{array}{l}\text { No. of cells } \\
\text { observed }(\%)\end{array}$ & $\begin{array}{l}55 \\
(50.0)\end{array}$ & $\begin{array}{l}55 \\
(50.0)\end{array}$ & & Non & $\begin{array}{l}110 \\
(100.0)\end{array}$ \\
\hline \multicolumn{6}{|c|}{ Specimen RD-8503 } \\
\hline Chrom. nos. & 41 & 42 & 43 & \multirow{2}{*}{$\begin{array}{l}\text { Robert. } \\
\text { fission }\end{array}$} & \multirow{2}{*}{$\begin{array}{l}\text { Total no. of cells } \\
\text { observed }(\%)\end{array}$} \\
\hline No. of B's & 2 & 3 & 4 & & \\
\hline $\begin{array}{l}\text { No. of cells } \\
\text { observed }(\%)\end{array}$ & $\begin{array}{l}7 \\
(4.8)\end{array}$ & $\begin{array}{l}100 \\
(68.5)\end{array}$ & $\begin{array}{l}39 \\
(26.7)\end{array}$ & no. 5 & $\begin{array}{l}146 \\
(100.0)\end{array}$ \\
\hline
\end{tabular}

On the occurrence of the B-chromosomes in the Japanese raccoon dogs, the present authors (Yosida and Wada 1984d) classified it into three types; monomodal distribution (Type 1), the bimodal distribution (Type 2) and the wide distribution of B's (Type 3). The occurrence of the B-chromosomes in the present specimen was a typical case of the Type 2. As a possible reason for the occurrence of the Type 2, they suggested that the non-disjunction of the B-chromosome would have occurred in the early developing stage. In this case the nondisjunction would take place in one cell side at two cell stage of the ontogeny. The cell with one B-chromosome would be degenerated. Although the other explanations such as the double fertilization are considered as the cause of the mosaic specimen, the non-disjunction seems to be the most probable from the observations of the other many specimens.

2) Specimen RD-8503 with the Robertsonian fission of the pair no. 5. The somatic cells of this specimen was characterized by the mosaic having three cell types with $2 n=41,42$ and 43 . They had 2 B's, 3 B's and 4 B's, respectively. Among 146 cells observed so far, 100 cells $(68.5 \%)$ had 3 B's, 39 cells $(26.7 \%)$ contained 4 B's and the remaining 7 cells $(4.8 \%$ ) involved 2 B's (Table I). All these cells had two extraordinary acrocentric chromosomes, while one metacentric chromosome was reduced from the standard karyotype. By the G-banding staining it was clearly shown that one of the metacentric pair no. 5 was broken at the centromeric region and two acrocentrics increased in its karyotype (Figs. 1 and 2). By such a Robertsonian fission of the autosome, an increase of the one chromosome number was observed in all cells of this specimen. The distribution of the B-chromosomes in this specimen was the monomodal type which was classified as Type 1.

The Robertsonian fission of the no. 5 chromosome has been observed in one specimen (RD-8410) by the present authors (Yosida and Wada 1984b), but the simultaneous fission of three chromosomes, nos. 5, 8 and 11, has been observed in that specimen. The finding of the Japanese raccoon dog with a single fission of the pair no. 5 was the first in the present work. So far as the present authors observed the chromosomes of 37 specimens, the Robertsonian fission of the metacentric chromosomes was observed in 9 specimens including the present material. Among them 8 specimens had a single fission in pair no. 8 (3 specimens), no. 6 (one), no. 5 (one) and unknown chromosome pair (3), but the 

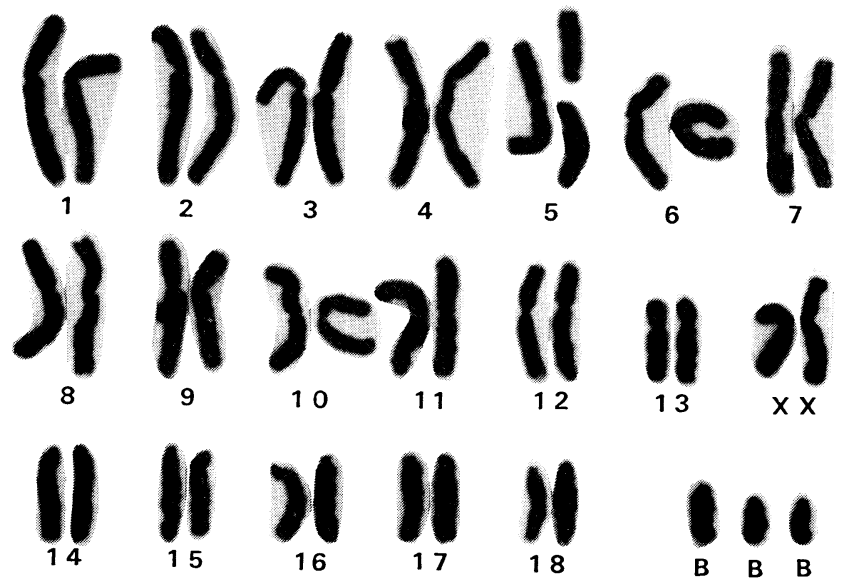

1

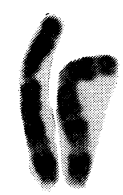

1
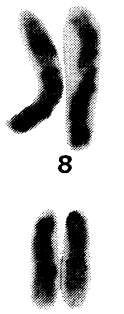

2

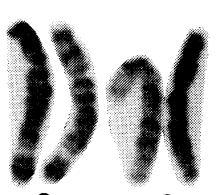

3

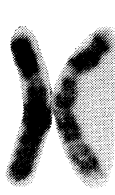

4
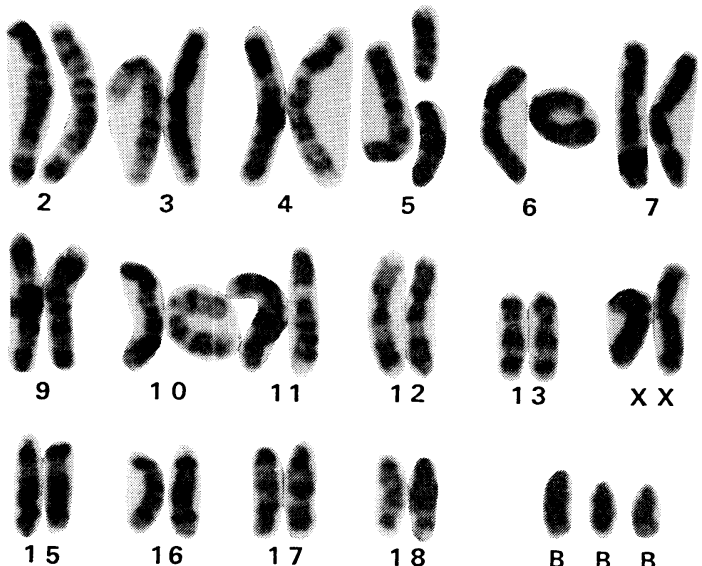

16
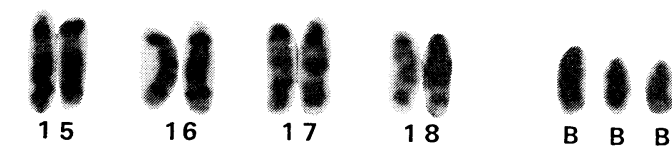

Figs. 1-2. Karyotype of the Japanese raccoon dog (RD-8503) with 3 B-chromosomes and the Robertsonian fission of the pair no. 5 . 1: Conventional Giemsa staining. 2: G-banding of staining to the same cell as Fig. 1. Scale corresponds to $10 \mu \mathrm{m}$.

remaining one specimen had 3 Robertsonian fission in the pair nos. 5, 8 and 11. Among 13 biarmed autosome pairs (nos. 1 to 13) in the Japanese raccoon dog, the Robertsonian fission was found in 4 chromosome pairs; nos. 5, 6, 8 and 11. One of the present authors proposed an idea of the sequential occurrence in the chromosome evolution (Yosida 1983). The Robertsonian fission in the Japanese raccoon dog would occur through the sequentiality of the chromosome evolution from one to the others.

Summary. The B-chromosomes and the Robertsonian fission in two Japanese raccoon dogs ( $\mathrm{RD}-8501$ and $\mathrm{RD}-8503$ ) collected in Kanagawa-ken are described in the present paper. The RD-8501 specimen is characterized by having an equal number of two cell types with 2 and 3 B-chromosomes. The other specimen, 
RD-8503, having three cell types due to $2 \mathrm{~B}$ 's, 3 B's and 4 B's, is remarkable by having a single Robertsonian fission of the pair no. 5 .

Acknowledgments. The present authors are grateful to Emeritus Professor, Sajiro Makino, M. J. A., for his critical reading of this manuscript. They are also indebted to Mr. Yutaka Oosaka of the Yokohama Municipal Nogeyama Zoo for the collsction of the materials.

\section{References}

Wada, M. Y., and Yosida, T. H.: La Kromosomo (II), 35-36, 1117-1121 (1984).

Yosida, T. H.: Proc. Japan Acad., 59B, 5-8 (1983).

Yosida, T. H., and Wada, M. Y.: ibid., 60B, 289-292 (1984a).

-—: ibid., 60B, 293-296 (1984b).

- : ibid., 60B, 297-300 (1984c).

——: ibid., 60B, 301-305 (1984d).

——: ibid., 61B, 375-378 (1985a).

—: ibid., 61B, 379-382 (1985b).

——: ibid., 61B, 383-386 (1985c).

Yosida, T. H., Harada, M., and Wada, M. Y.: ibid., 61B, 121-124 (1985).

Yosida, T. H., Wada, M. Y., and Ward, O. G.: ibid., 59B, 267-270 (1983).

Yosida, T. H. et al.: ibid., 60B, 17-20 (1984). 